\title{
Pengaruh Ekstrak Buah Jamblang Terhadap Kadar Antosianin, Aktivitas Antioksidan Dan Sifat Organoleptik Es Krim Ubi Ungu
}

\author{
Ramzy Arif Satriyo Bima Anggara*1, A'immatul Fauziyah ${ }^{1}$, Ibnu Malkan Bakhrul Ilmi ${ }^{1}$ \\ ${ }^{1}$ Program Studi Gizi, Fakultas Ilmu kesehatan, Universitas Pembangunan Nasional Veteran Jakarta, Jakarta, \\ Indonesia
}

Author's Email Correspondence (*): aimmatulfauziyah@upnvj.ac.id (081285437237)

\begin{abstract}
Abstrak
International Diabetes Federation (IDF) menyatakan bahwa pada tahun 2013, Diabetes Mellitus (DM) tipe 2 menyerang 382 juta orang. Buah jamblang memiliki kandungan fenolik yang tinggi untuk memperbaiki kondisi DM Tipe 2. Penelitian ini bertujuan untuk menganalisis pengaruh ekstrak buah jamblang terhadap penerimaan sensori, kandungan antosianin, dan aktivitas antioksidan es krim ubi jalar ungu. Rancangan penelitian ini adalah eksperimen dengan rancangan acak lengkap dengan dua ulangan pada setiap formula. Terdapat 3 level buah jamblang pada es krim ubi jalar ungu yaitu Formula 1 sebanyak 30\%, Formula 2 sebanyak 40\%, Formula 3 sebanyak 50\%. Uji organoleptik menunjukkan bahwa esktrak buah jamblang pada es krim ubi jalar ungu meningkatkan penerimaan warna secara signifikan $(\mathrm{p}<0,005)$. Ekstrak buah jamblang pada es krim ubi jalar ungu meningkatkan aktivitas antosianin dan antioksidan secara signifikan ( $\mathrm{p}<0,05)$. Formula terbaik adalah F3 dengan kandungan energi, kadar air, karbohidrat, protein, lemak, abu $52 \mathrm{kkal} ; 87 \% ; 9,6 \%, 1,83 \% ; 0,72 \% ; 0,39 \%$.
\end{abstract}

Kata Kunci: Es Krim, Antosianin, Antioksidan, Buah Jamblang, Ubi Ungu

How to Cite:

Anggara, R., Fauziyah, A., \& Ilmi, I. (2021). Pengaruh Ekstrak Buah Jamblang Terhadap Kadar Antosianin, Aktivitas Antioksidan Dan Sifat Organoleptik Es Krim Ubi Ungu. Ghidza: Jurnal Gizi Dan Kesehatan, 5(1), 95 - 107. https://doi.org/10.22487/ghidza.v5i1.207

\section{Published by:}

Tadulako University

Address:

Soekarno Hatta KM 9. Kota Palu, Sulawesi Tengah, Indonesia.

Phone: +628525357076

Email: ghidzajurnal@gmail.com
Article history :

Received : 08022021

Received in revised form : 10072021

Accepted : 11072021

Available online : 13072021 
Abstract

The International Diabetes Federation (IDF) states that in 2013, Type 2 Diabetes Mellitus (DM) affected 382 million people. Java plum (JP) had high phenolic content for improving Type $2 \mathrm{DM}$ condition. The aim of this research was to analyze effect of java plum (JP) substitution sensory acceptance, antocyanin content and antioxidant activity of purple sweet potato (PSP) ice cream. The design was experimental study with completely randomized with two repetitions on each formula. There are 3 levels of jamblang fruit in purple sweet potato ice cream, Formula 1 as much as $30 \%$, Formula 2 as much as $40 \%$, Formula 3 as much as 50\%. Organoleptic test showed that JP on PSP ice cream increased color acceptance significantly $(\mathrm{p}<0.005)$. JP on PSP ice cream increased antocyanin and antioxidant activity significantly $(\mathrm{p}<0.05)$. The best formula was F3 with energy, moisture, carbohydrate, protein, fat, ash content were $52 \mathrm{kkal} ; 87 \%$; 9,6\%, $1,83 \% ; 0,72 \% ; 0,39 \%$.

\section{Keywords : Ice cream, Java Plum, Purple Sweet Potato, Antocyanin, Antioxidant}

\section{PENDAHULUAN}

International Diabetes Federation (IDF) menyatakan bahwa pada tahun 2013 angka kejadian diabetes mellitus diperkirakan mencapai 382 juta jiwa. Angka tersebut diperkirakan akan meningkat menjadi 592 juta jiwa pada tahun 2035 (Kemenkes RI, 2014). Prevalensi penyakit tidak menular mengalami peningkatan setiap tahunnya. Salah satu penyakit tersebut adalah diabetes mellitus. Hasil Riset Kesehatan Dasar(RISKESDAS) menurut konsensus perkeni 2011 penduduk yang berusia $\geq 15$ tahun yang menderita DM sebesar 6,9\% pada tahun 2013 dan pada tahun 2018 menjadi 8,5\%, sedangkan berdasarkan konsensus kriteria perkeni 2015 pada tahun 2018 prevalensi DM sebesar 10,9\%. (Kementerian Kesehatan RI Badan Penelitian dan Pengembangan, 2018).

Diabetes melitus (DM) merupakan penyakit metabolik ditandai dengan tingginya kadar glukosa darah (hiperglikemia) akibat kurangnya sekresi insulin, kerja insulin maupun keduanya (Fauziyah dkk, 2019). Jumlah radikal bebas pada DM tipe 2 sangatlah tinggi. Radikal bebas dalam jumlah yang berlebih didalam tubuh akan mengakibatkan peningkatan peroksidasi lipid atau MDA (Malondialdehyde). Peningkatan MDA akan mengakibatkan kebocoran membran sel, menginaktivasi membran berikatan dengan enzim, serta menginaktivasi reseptor molekul permukaan menuju gangguan regulasi sel (Kristina dkk, 2015). Radikal bebas juga memicu munculnya stres oksidatif yang menginduksi resistensi insulin pada jaringan perifer dan merusak sekresi insulin dari sel beta pankreas sehingga mengakibatkan DM tipe 2 (Setiawan, 2005). Stress oksidatif tersebut dapat diredam oleh antioksidan. Asupan antioksidan yang cukup akan membantu mengurangi aktivitas radikal bebas.

Salah satu pangan tinggi antioksidan adalah buah jamblang. Buah jamblang memiliki aktivitas antioksidan sebesar 33 ppm (Muttakin dkk, 2019). Kandungan antosianin yang terdapat pada buah jamblang sebesar $161 \mathrm{mg} / 100$ gram (Latifa, 2015). Selain buah jamblang, ubi ungu juga merupakan sumber antioksidan. Aktivitas antioksidan pada ubi ungu sebesar 65,35 ppm 
sehingga termasuk antioksidan yang kuat (Arifuddin, 2018). Kandungan antosianin pada ubi ungu segar adalah $61,85 \mathrm{mg} / 100 \mathrm{mg}$.

Es krim merupakan makanan olahan yang banyak digemari oleh setiap kalangan mulai dari anak-anak, remaja hingga orang tua. Es krim sering kali dikonsumsi terutama di negara yang beriklim tropis seperti di Indonesia. Konsumsi es krim di Indonesia berkisar 0,5 liter/orang/tahun dan meningkat setiap tahunnya seiring dengan banyaknya orang yang menggemari es krim (Widiantara, 2019).

Adanya radikal bebas yang dapat memicu munculnya stres oksidatif maka dibutuhkan zat tinggi antioksidan alami yang dapat diperoleh dari buah jamblang dan ubi ungu. Tingginya antioksidan khususnya antosianin pada kedua bahan baku yaitu buah jamblang dan ubi ungu maka dipilihlah es krim sebagai bentuk produk olahan karena es krim dapat menjaga stabilitas dan meminimalisir terjadinya degradasi kadar antosianin yang terdapat pada bahan baku dikarenakan pembuatan es krim yang proses pemanasannya relatif minimal. Sehingga kedua bahan tersebut dapat dibuat menjadi es krim tinggi antioksidan antosianin. Dibuatnya es krim tersebut diharapkan dapat memperbaiki kondisi hiperglikemia. Berdasarkan paparan diatas peneliti bermaksud untuk menganalisis pengaruh ekstrak buah jamblang terhadap kadar antosianin, aktivitas antioksidan dan sifat organoletik es krim ubi ungu.

\section{METHOD}

Penelelitian ini merupakan jenis penelitian eksperimen dengan metode Rancangan Acak Lengkap (RAL) dengan 1 perlakuan dan 2 kali ulangan pada formula pertama ekstrak buah jamblang sebanyak 30\%, formula kedua ekstrak buah jamblang sebanyak 40\%, dan formula ketiga sebanyak 50\%. Tahap pertama pembuatan es krim ubi ungu dengan ekstrak buah jamblang adalah dengan membuat ekstrak ubi ungu mengacu pada penelitian Adi dkk (2014). Perbandingan air dan ubi ungu yaitu 2:1. Ubi ungu dibersihkan terlebih dahulu dengan cara dicuci, kemudian setelah itu ubi ungu dipotong. Ubi ungu yang sudah dipotong maka dilakukan pengukusan selama 15 menit setelah itu bersihkan kulit ari yang masih ada tersisa pada ubi ungu. Selanjutnya ubi ungu dan air diblender bersama, lalu puree ubi ungu disaring dan dipisahkan dengan ampasnya dengan menggunakan kain saring.

Tahap kedua adalah membuat ekstrak buah jamblang mengacu pada (Wati, 2018) buah jamblang disortasi berdasarkan tingkat kematangan, setelah itu dicuci dengan air mengalir, selanjutnya menghilangkan biji buah, buah dihancurkan dengan blender lalu ditambahkan air dengan rasio 1:2 dan disaring sehingga diperoleh ekstrak buah jamblang.

Tahap ketiga yaitu pembuatan es krim ubi ungu dengan ekstrak buah jamblang mengacu pada Sanggur (2017) susu skim dipasteurisasi selama 25 detik dengan suhu $80^{\circ} \mathrm{C}$. Tambahkan 
kuning telur sebanyak 5\%, maizena $2 \%$ dan gula untuk penderita DM 2\%. Setelah itu dinginkan hingga mencapai suhu ruang. Langkah selanjutnya adalah mencampurkan yaitu formulasi 1 sebanyak 40\% ekstrak ubi ungu dan buah jamblang 30\%, formulasi 2 sebanyak $30 \%$ ekstrak ubi ungu dan buah jamblang 40\%, formulasi 3 sebanyak 20\% ekstrak ubi ungu dan buah jamblang 50\% dengan bahan yang sudah diolah sebelumnya. Setelah tercampur rata maka adonan es krim dimasukan ke dalam ice cream maker. Setelah itu adonan yang diperoleh yaitu 1 liter dan dikemas dalam cup dengan takaran saji 100 gram.

Pengukuran kadar antosianin adalah dengan metode spektrofotometri. Langkah pertama adalah melarutkan sampel dengan menggunakan buffer KCI pH 1 pada panjang gelombang $510 \mathrm{~nm}$ hingga diperoleh absorbansi $<1$,2. Selanjutnya dilakukan pengukuran absorbansi akuades pada panjang gelombang $510 \mathrm{~nm}$ dan $700 \mathrm{~nm}$. Panjang gelombang maksimum yang dapat digunakan untuk sianidin-3-glukosida adalah panjang gelombang $510 \mathrm{~nm}$. Sedangkan, panjang gelombang $700 \mathrm{~nm}$ digunakan untuk mengoreksi endapan yang tertinggal pada sampel. Lalu, persiapkan dua larutan serta sampel yang akan digunakan. Sampel pertama menggunakan buffer KCI dengan $\mathrm{pH} 1$ dan untuk samper kedua menggunakan buffer Nasitrat dengan $\mathrm{pH} 4,5$. Berdasarkan DF (dilution factor) setiap sampel dilarutkan dengan larutan buffer yang telah ditetapkan untuk melarutkan sampel. Sebelum diukur, sampel yang dilarutkan menggunakan dengan buffer $\mathrm{pH} 1$ didiamkan selama 15 menit, sedangkan untuk sampel yang dilarutkan dengan menggunakan buffer $\mathrm{pH}$ 4,5 sebelum diukur, sampel dibiarkan bercampur selama 5 menit setelah itu siap untuk diukur. Buffer $\mathrm{Ph} 1$ dan buffer $\mathrm{pH}$ 4,5 digunakan sebagai blanko untuk mengukur absorbansi setiap larutan pada panjang gelombang $510 \mathrm{~nm}$ dan $700 \mathrm{~nm}$ (Meidayanti, 2015).

Aktivitas antioksidan ditentukan menggunakan metode penangkapan radikal (radical scavenging) dengan menggunakan DPPH (Sandhiutami dkk, 2011). Aktivitas antioksidan diukur berdasarkan suatu senyawa yang diuji mampu bereaksi terhadap radikal DPPH dengan panjang gelombang $517 \mathrm{~nm}$. Pembuatan larutan DPPH 0,5 $\mathrm{mm}$ dibuat dengan menggunakan serbuk DPPH sebanyak 19,7 mg yang dimasukkan ke dalam labu takar $100 \mathrm{ml}$ lalu ditambahkan metanol untuk melarutkan serbuk DPPH. Sampel sebanyak 2 gram yang telah diesktraksi dengan metanol lalu dihaluskan dan dimasukkan ke dalam erlenmeyer. Pengujian dilakukan dengan membuat seri konsentrasi, yaitu 100, 500, 1000, 2000, 4000, 8000, dan 16000 ppm. Setiap seri konsentrasi diberikan larutan DPPH 0,5 Mm sebanyak $1 \mathrm{ml}$. Selanjutnya sampel dan DPPH divortex selama 1 menit hingga tercampur merata dan didiamkan 30 menit pada suhu ruang, sisa DPPH ditentukan dengan spektrofotometri berdasarkan panjang gelombang yang sudah ditentukan yaitu $517 \mathrm{~nm}$. Pengujian dilakukan juga untuk pengukuran terhadap blangko dengan larutan DPPH yang tidak mengandung 
bahan uji, serta kontrol positif kuersetin. Hasil data aktivitas antioksidan penangkap radikal DPPH dianalisis dan masing-masing dihitung nilai IC50 melalui analisis probit. IC50 adalah konsentrasi yang mampu menghambat 50\% DPPH. Aktivitas penangkap radikal DPPH (\%) dihitung dengan rumus berikut:

\section{\%Inhibisi : $\left(\frac{\text { A blangko-A Sampel }}{A \text { Blangko }}\right) \times 100 \%$}

Persamaan regresi linear yang diperoleh dalam bentuk persamaan $\mathrm{y}=\mathrm{a}+\mathrm{bx}$. Persamaan tersebut digunakan untuk mencari nilai 1C50 (inhibitor concentration $50 \%$ ) dari sampel dengan menyatakan nilai y sebesar 50 dan nilai $x$ yang akan diperoleh dari 1C50 (Rahmayani,2013)

Untuk menguji tingkat kesukaan, menggunakan uji organoleptik dengan metode uji hedonik (kesukaan) dengan parameter warna, aroma, tekstur, dan rasa serta skala penilaian (1) sangat tidak suka, (2) tidak suka, (3) netral, (4) suka, dan (5) sangat suka. Uji organoleptik dilakukan oleh 30 panelis semi terlatih yang merupakan mahasiswa aktif S1 Ilmu Gizi UPN Veteran Jakarta semester $4-8$ yang telah mendapatkan pembelajaran mengenai organoleptik.

\section{HASIL}

\section{Hasil Uji Organoleptik Pengaruh Ekstrak Buah Jamblang Terhadap Sifat Organoleptik Es Krim Ubi Ungu}

Hasil dari uji organoleptik disajikan pada Tabel 1, nilai median tertinggi pada parameter warna terdapat pada F2 yaitu 4 (suka), pada parameter aroma nilai median tertinggi yaitu pada F1 dengan nilai 3 (netral). Pada parameter tekstur nilai median tertinggi terdapat pada F1 yaitu 4 (suka), sedangkan pada paramater rasa pada F3 yaitu 3 (netral). Hasil uji organoleptik diuji dengan menggunakan uji normalitas untuk melihat sebaran data, dan apabila tidak terdistribusi normal dilakukan uji Kruskal Wallis, jika terdapat perbedaan dilanjutkan dengan uji Mann Whitney.

Tabel 1 Hasil Uji Hedonik Es Krim Ubi Ungu dengan Ekstrak Buah Jamblang

\begin{tabular}{|c|c|c|c|}
\hline \multirow[t]{2}{*}{ Parameter } & \multicolumn{3}{|c|}{$\begin{array}{l}\text { Nilai Median Uji Hedonik Es Krim Ubi Ungu } \\
\text { dengan Ekstrak Buah Jamblang }\end{array}$} \\
\hline & F1 & $\mathrm{F} 2$ & F3 \\
\hline Warna & $2(1-5)^{\mathrm{a}}$ & $3(1-5)^{\mathrm{a}}$ & $4(1-5)^{b}$ \\
\hline Aroma & $3(1-4)^{\mathrm{a}}$ & $3(1-4)^{\mathrm{a}}$ & $3(1-4)^{\mathrm{a}}$ \\
\hline Rasa & $3(2-5)^{\mathrm{a}}$ & $3(1-5)^{\mathrm{a}}$ & $3(1-5)^{\mathrm{a}}$ \\
\hline Tekstur & $3(2-4)^{a}$ & $3(1-5)^{\mathrm{a}}$ & $4(1-5)^{a}$ \\
\hline
\end{tabular}

Hasil uji Kruskal Wallis menunjukkan dengan adanya ekstrak buah jamblang berpengaruh nyata $(\mathrm{p}=0,000)$ terhadap parameter warna dari produk es krim, sehingga 
dilanjutkan dengan uji Mann Whitney. Pada parameter aroma hasil uji Kruskal Wallis menunjukkan tidak adanya pengaruh nyata ekstrak buah jamblang pada produk es krim ubi ungu $(\mathrm{p}=0,479)$. Hasil perhitungan dari uji Kruskal Wallis menunjukkan pada produk es krim ubi ungu dengan ekstrak buah jamblang pada parameter tekstur tidak ada pengaruh nyata $(\mathrm{p}=0,091)$ Hasil perhitungan dari uji Kruskal Wallis menunjukkan pada produk es krim ubi ungu dengan ekstrak buah jamblang pada parameter rasa tidak ada pengaruh nyata $(\mathrm{p}=0,491)$ terhadap produk es krim.

\section{Hasil Uji Kadar Antosianin dan Aktivitas Antioksidan Pengaruh Ekstrak Buah Jamblang Terhadap Kadar Antosianin Es Krim Ubi Ungu}

Es krim ubi ungu dengan ekstrak buah jamblang memiliki kadar antosianin sebesar 94,37 \pm 0,0452 pada F1, pada F2 sebesar 130,89 \pm 0,2126, dan pada F3 sebesar 208,63 $\pm 0,7205$. Es krim ubi ungu dengan ekstrak buah jamblang pada F3 memiliki kadar antosianin tertinggi sedangkan F1 memiliki kadar antosianin terendah. Hasil uji aktivitas antioksidan es krim ubi ungu dengan ekstrak buah jamblang memiliki aktivitas antioksidan sebesar $13.784 \pm 1,458$ pada F1, pada F2 sebesar 10.129 \pm 4,644, dan pada F3 sebesar $4365 \pm 0,756$. Es krim ubi ungu dengan ekstrak buah jamblang pada F3 memiliki aktivitas antioksidan tertinggi sedangkan F1 memiliki aktivitas antioksidan terendah. Hasil dari uji kadar antosianin dan aktivitas antioksidan disajikan pada Tabel 2.

\section{Tabel 2 Kadar Antosianin dan Aktivias Antioksidan Es Krim Ubi Ungu dengan Ekstrak Buah Jamblang}

\begin{tabular}{cccc}
\hline \multirow{2}{*}{ Komponen } & \multicolumn{3}{c}{ Hasil Kadar Antosianin dan Aktivitas Antioksidan } \\
& \multicolumn{3}{c}{ Sampel } \\
\cline { 2 - 4 } & F1 & F2 & F3 \\
\hline $\begin{array}{c}\text { Kadar Antosianin } \\
\text { (mg/L) }\end{array}$ & $94,37 \pm 0,04^{\mathrm{a}}$ & $130,89 \pm 0,21^{\mathrm{b}}$ & $208,63 \pm 0,72^{\mathrm{c}}$ \\
\hline $\begin{array}{c}\text { Aktivitas } \\
\text { Antioksidan } \\
(\mathrm{ppm})\end{array}$ & $13.784 \pm 1,45^{\mathrm{a}}$ & $10.129 \pm 4,64^{\mathrm{b}}$ & $4.365 \pm 0,75^{\mathrm{c}}$ \\
\hline
\end{tabular}

Hasil sidik ragam (ANOVA) menunjukkan ekstrak buah jamblang berpengaruh nyata $(\alpha=0,000)$ terhadap kadar antosianin es krim ubi ungu. Uji Duncan menunjukkan, kadar antosianin es krim F1 berbeda nyata $(\mathrm{p}=1,000)$ dan lebih rendah dibandingan dengan es krim F2 dan F3. Selanjutnya kadar antosianin es krim ubi ungu ekstrak buah jamblang F2 berbeda nyata $(\mathrm{p}=1,000)$ dan lebih rendah dibandingkan dengan F3. Hasil sidik ragam (ANOVA) menunjukkan bahwa ekstrak buah jamblang berpengaruh nyata $(\alpha=0,000)$ terhadap aktivitas antioksidan es krim ubi ungu. Hasil uji Duncan menunjukkan bahwa aktivitas antioksidan es krim F1 berbeda nyata $(\mathrm{p}=1,000)$ dan lebih rendah dibandingan dengan F2 dan F3. Aktivitas antioksidan es krim ubi ungu ekstrak buah jamblang F2 berbeda nyata $(\mathrm{p}=1,000)$ dan lebih rendah dibandingkan dengan F3. 


\section{Penentuan Formula Terpilih Es Krim Ubi Ungu Dengan Ekstrak Buah Jamblang}

Formula terpilih ditentukan menggunakan metode perbandingan eksponensial (MPE). Metode perbandingan eksponensial (MPE) adalah sebuah metode menentukan susunan prioritas alternatif keputusan dengan kriteria jamak. MPE dapat mengurangi bias yang bisa terjadi dalam proses analisis, karena hasil nilai skor menggambarkan susunan prioritas menjadi besar sehingga susunan prioritas alternatif keputusan menjadi lebih nyata (Juhardi dkk, 2019). Kriteria yang dipertimbangkan untuk penentuan formula terpilih adalah hasil kadar antosianin, aktivitas antioksidan dan uji hedonik produk. Setiap parameter memiliki bobot yang berbeda. Penentuan bobot berdasarkan pada parameter yang ingin diunggulkan dari produk es krim ubi ungu dengan ekstrak buah jamblang. Parameter uji hedonik yaitu tingkat kesukaan terhadap warna, aroma, rasa, dan tekstur memiliki bobot nilai masing - masing 5\%. Kriteria aktivitas antioksidan memiliki nilai bobot $30 \%$, sedangkan kadar antosianin memiliki bobot nilai sebesar $50 \%$. Data pada setiap bobot akan diurutkan secara descending. Kriteria parameter yang digunakan akan diberikan peringkat berdasarkan hasil analisisnya. Peringkat 1 akan diberikan pada formula dengan hasil uji atau analisis yang terbaik dan untuk peringkat 3 untuk hasil uji atau analisis yang kurang baik. Hasil skor diperoleh dari peringkat yang dikalikan dengan bobot masingmasing parameter.

Parameter kadar antosianin memiliki bobot paling tinggi karena kadar antosianin merupakan variabel yang diunggulkan dalam produk es krim ubi ungu dengan ekstrak buah jamblang. Parameter aktivitas antioksidan memiliki bobot tertinggi kedua setelah kadar antosianin. Parameter uji hedonik yaitu warna, aroma, rasa dan tekstur juga menjadi kriteria yang menentukan dalam formula terpilih karena dari daya terima es krim yang memiliki pengaruh terhadap tingkat konsumsi es krim. Hasil uji rangking disajikan pada Tabel 3.

Tabel 3 Hasil Uji Ranking Kadar Antosianin, Aktivitas Antioksidan dan Uji Hedonik Es Krim Ubi Ungu dengan Ekstrak Buah Jamblang

\begin{tabular}{cccccccc}
\hline \multirow{2}{*}{ Parameter } & \multirow{2}{*}{ Bobot } & \multicolumn{7}{c}{ Skor Formula } \\
\cline { 3 - 8 } & & Rank & Skor & Rank & Skor & Rank & Skor \\
\cline { 2 - 8 } & $5 \%$ & 3 & 0,15 & 2 & 0,1 & 1 & 0,05 \\
\hline Warna & $5 \%$ & 1 & 0,05 & 3 & 0,15 & 2 & 0,1 \\
\hline Aroma & $5 \%$ & 1 & 0,05 & 2 & 0,1 & 3 & 0,15 \\
\hline Rasa & $5 \%$ & 2 & 0,1 & 3 & 0,15 & 1 & 0,05 \\
\hline Tekstur & $50 \%$ & 3 & 1,5 & 2 & 1 & 1 & 0,5 \\
\hline Antosianin & $30 \%$ & 3 & 0,9 & 2 & 0,6 & 1 & 0,3 \\
\hline Aktivitas & & & & & & & \\
Antioksidan & $100 \%$ & - & $\mathbf{2 , 7 5}$ & - & $\mathbf{2 , 1}$ & - & $\mathbf{1 , 1 5}$ \\
\hline Total & - & $\mathbf{3}$ & - & $\mathbf{2}$ & - & $\mathbf{1}$ & -
\end{tabular}


Berdasarkan uji ranking, nilai ranking pada formula F1,F2,F3 yaitu tiga, dua, satu. Formulasi F3 es krim ubi ungu menjadi fomula terpilih dengan 50\% memiliki skor terendah yang berarti menjadi rangking yang tertinggi.

\section{PEMBAHASAN}

Warna merupakan sifat sensoris yang bisa secara langsung dilihat pada pertama kali panelis melihat produk (Negara dkk, 2016). Warna merupakan sifat dari pangan yang dapat menarik perhatian konsumen serta memberikan kesan bahwa produk tersebut disukai atau tidak (Agusta, 2018). Jika suatu pangan tidak disukai maka dapat dikatakan bahwa warna pada produk pangan memberikan kesan yang tidak baik (Sanggur, 2017).Pada penelitian ini terdapat perbedaan warna yang signifikan pada formulasi es krim ubi ungu dengan ekstrak buah jamblang. ekstrak buah jamblang terhadap es krim ubi ungu akan meningkatkan angka kesukaan terhadap warna karena intensitas warna ungunya meningkat. Peningkatan intensitas warna disebabkan karena adanya peningkatan kadar antosianin akibat susbtitusi buah jamblang terhadap es krim ubi ungu. Kadar antosianin yang terdapat pada buah jamblang yaitu $161 \mathrm{mg}$ (Latifa, 2015) sedangkan kadar antosianin pada ubi ungu adalah 110 mg (Ginting dkk, 2015). Pada penelitian ini produk F3 paling disukai oleh panelis dengan persentase ekstrak buah jamblang sebesar 50\%, hal ini sesuai dengan dengan penelitian Lestari yang membuat sirup dengan ditambahkan buah jamblang (2013) menyatakan bahwa semakin banyak penambahan ekstrak buah jamblang akan memberi warna semakin menarik pada produk sehingga akan meningkatkan kesukaan panelis terhadap parameter warna (Anggraeni dkk, 2018).

Hasil uji hedonik es krim ubi ungu dengan ekstrak buah jamblang disajikan pada tabel 1. Nilai median tingkat kesukaan panelis pada karakteristik aroma produk F1, F2, F3 adalah 3 (Netral). Hasil tersebut menunjukkan bahwa es krim ubi ungu dengan ekstrak buah jamblang memiliki daya terima yang cukup baik terhadap aroma produk. Hal ini sesuai dengan pernyataan Maulida dan Atma (2014) yang menyatakan bahwa es krim yang terlalu dingin akan menyebabkan wewangian dalam es krim tidak volatil (menguap) ketika dicicipi didalam mulut, sehingga membuat es krim hanya sedikit sekali memiliki aroma yang dapat terdeteksi atau bahkan tidak terdeteksi sama sekali. Maka, hal tersebut membuat es krim tidak memiliki aroma.

Parameter lain nilai median tingkat kesukaan panelis pada karakteristik rasa produk F1, F2, F3 adalah 3 (Netral). Hasil tersebut menunjukkan bahwa es krim ubi ungu dengan ekstrak buah jamblang memiliki daya terima yang cukup baik terhadap rasa produk. Menurut pendapat (Widiantara, 2019) tingkat kemanisan akan mempengaruhi rasa. Kandungan gula yang terdapat pada es krim lebih mempengaruhi tingkat kemanisan. Namun, karena pemberian gula yang sama pada setiap formulasi sehingga tidak terdapat pengaruh yang signifikan terhadap rasa. Selain itu 
pada penelitian ini ekstrak buah jamblang hanya berbeda $50 \mathrm{ml}$ untuk setiap formulasi sehingga rasa pada es krim tidak terlalu signifikan akan perbedaan rasa. Hal ini sesuai dengan penelitian yang dilakukan oleh (Arini, 2019) menyatakan bahwa variasi penambahan bahan seperti ekstrak buah jamblang yang berbeda tipis akan menghasilkan rasa yang hampir sama pada setiap formulasi.

Hasil uji hedonik es krim ubi ungu dengan ekstrak buah jamblang pada Tabel 1. Nilai median tingkat kesukaan panelis pada karakteristik tekstur produk F1 dan F2 ialah 3 (Netral), sedangkan F3 adalah 4 (suka). Hasil tersebut menunjukkan bahwa es krim ubi ungu dengan subtitusi ekstrak buah jamblang F3 memiliki median tingkat kesukaan tertinggi terhadap parameter tekstur. Penelitian ini berbeda dengan penelitian yang dilakukan oleh Pratiwi (2015) yang menyatakan bahwa peningkatan buah jamblang akan menurunkan kesukaan panelis terhadap tekstur produk (Wati, 2018). Namun pada penelitian ini seiring dengan penambahan persentase ekstrak buah jamblang maka produk makin disukai. Pada penelitian ini produk F3 dengan ekstrak buah jamblang 50\% paling disukai panelis pada parameter tekstur.

Hasil uji kadar antosianin dan aktivitas antioksidan tertinggi terdapat pada F3, sejalan dengan Pratiwi (2015) yang menyatakan bahwa semakin tinggi konsentrasi buah jamblang, maka semakin tinggi kadar antosianin aktivitas antioksidan dalam es krim. Pada penelitian lain yang dilakukan oleh (Wati, 2018) menunjukkan bahwa seiring dengan meningkatnya penambahan sari buah duwet/ jamblang dalam pembuatan minuman jelly drink maka terjadi peningkatan kadar antosianin pada setiap formula. Peningkatan kadar antosianin pada penelitian ini disebabkan oleh pigmen dari ekstrak buah jamblang yang mengandung komponen zat aktif antosianin yang lebih tinggi dibandingkan dengan ubi ungu, sehingga semakin tinggi kadar ekstrak buah jamblang, maka kadar antosianinnya akan semakin meningkat (Wati, 2018).

Takaran saji pada produk es krim diharapkan memiliki kadar antosianin yang dapat menurunkan kadar glukosa darah dan dapat mengurangi risiko diabetes mellitus tipe 2. Takaran saji es krim ditentukan berdasarkan peraturan BPOM nomor 22 Tahun 2019 yaitu 50-100 ml. Pada $100 \mathrm{ml}$ es krim ubi ungu dengan ekstrak buah jamblang memiliki kadar antosianin 20,86 mg, dan aktivitas antioksidan 4365 ppm. Pemberian antosianin sebanyak 30,8 mg/100 gram dapat meningkatkan kontrol glikemik dan status antioksidan, dan mengurangi peroksidasi lipid dan respon inflamasi pada pasien dengan diabetes tipe 2 (Moazen dkk 2013).

Kekurangan pada penelitian ini adalah Keterbatasan penelitian ini adalah proses pembuatan ekstrak buah jamblang dilakukan tidak sekaligus dalam satu hari melainkan berbeda hari dikarenakan buah jamblang merupakan buah musiman sehingga stok buah jamblang yang terbatas pada penjual. 
Kekuatan pada penelitian ini adalah hasil yang diperoleh yaitu menunjukkan bahwa terjadi peningkatan kadar antosianin dan aktivitas antioksidan seiring dengan bertambahnya persentase buah jamblang yang ditambahkan hal ini sesuai dengan literatur.

\section{KESIMPULAN}

Formulasi es krim ubi ungu dengan ekstrak buah jamblang yang dibuat menjadi tiga formula. Tingkatan ekstrak buah jamblang pada masing-masing formula yaitu F1 (30\%), F2 (40\%), F3 $(50 \%)$. Hasil uji organoleptik menunjukkan ekstrak buah jamblang berpengaruh nyata $(\mathrm{p}<0,05)$ terhadap tingkat kesukaan panelis pada parameter warna namun tidak berpengaruh nyata $(p>0,05)$ terhadap tingkat kesukaan panelis terhadap parameter rasa,aroma, dan tekstur. Ekstrak buah jamblang berpengaruh nyata $(\mathrm{p}<0,05)$ terhadap kadar antosianin. Ekstrak buah jamblang berpengaruh nyata $(\mathrm{p}<0,05)$ terhadap aktivitas antioksidan es krim ubi ungu. Peningkatan ekstrak buah jamblang berbanding lurus dengan peningkatan kadar antosianin dan aktivitas antioksidan. Sehingga peningkatan konsentrasi ekstrak buah jamblang, maka kadar antosianin dan aktivitas antioksidan meningkat. Formula es krim ubi ungu tepilih adalah F3 dengan ekstrak buah jamblang 50\%. Takaran saji produk sebesar $100 \mathrm{ml}$ mengandung energi $52 \mathrm{kkal}$, protein 1,83 gram, lemak 0,72 gram, karbohidrat 9,60 gram, kadar air 87,42\%, kadar abu 0,39\%, antosianin 20,86 mg, dan aktivitas antioksidan 4365 ppm

\section{UCAPAN TERIMA KASIH}

Terima kasih keapada Tuhan Yang Maha Esa serta Tim Penulis sehingga penelitian dan manuscript ini dapat selesai.

\section{DAFTAR PUSTAKA}

Adi, L., Praptiningsih, Y. and Tamtarini (2014) 'Pembuatan Es Krim Ekstrak Ubi Jalar Ungu (Ipomea batatas L.) dengan Variasi Jumlah Penambahan Susu Full Cream dan Karagenan', Berkala Ilmiah Pertanian, 1(1), pp. 1-5.

Agusta, E. N. (2018) 'Formulasi Nori Artifisial Berbahan Baku Bayam (Amaranthus hybridus L.)', Jurnal Agroindustri Halal, 3(1), pp. 19-27. doi: 10.30997/jah.v3i1.685.

Akbar, C. I., Arini, F. A. and Fauziyah, A. (2019) 'Teh Rambut Jagung dengan Penambahan Daun Stevia sebagai Alternatif Minuman Fungsional Bagi Penderita Diabetes Melitus Tipe 2', Jurnal Aplikasi Teknologi Pangan, 8(2), pp. 67-73. doi: 10.17728/jatp.3122.

Anggraeni, V. J., Ramdanawati, L. and Ayuantika, W. (2018) 'Penetapan Kadar Antosianin Total Beras Merah (Oryza nivara)', Jurnal Kartika Kimia, 1(1), pp. 11-16. doi: 
10.26874/jkk.v1i1.11.

Arifuddin, W. (2018) 'Aktivitas Antioksidan Senyawa Antosianin dari Ekstrak Etanol Ubi Jalar Ungu (Ipomoea batatas L)', Celebes Biodiversitas, 1(2), pp. 26-29.

Arini. M.D. 2019. Uji aktivitas antioksidan dan tingkat kesukaan panelis terhadap es krim cincau hijau (cyclea barbata miers). Skripsi. Universitas Sanata Dharma Yogyakarta

Ginting, E., Utomo, J. S. and Yulifianti, R. (2015) 'Potensi Ubijalar Ungu sebagai Pangan Fungsional', Iptek Tanaman Pangan, 6(1).

Juhardi, U. et al. (2019) 'Penerapan Metode Perbandingan Eksponensial Pada Penilaian Proses Belajar Mengajar di Fakultas Teknik Universitas Muhammadiyah Bengkulu’, 5(2).

Kementerian Kesehatan RI Badan Penelitian dan Pengembangan (2014) 'Hasil Utama Riset Kesehatan Dasar', Kementrian Kesehatan Republik Indonesia, pp. 1-100. Available at: http://www.depkes.go.id/resources/download/info-terkini/hasil-riskesdas-2014.pdf.

Kementerian Kesehatan RI Badan Penelitian dan Pengembangan (2018) 'Hasil Utama Riset Kesehatan Dasar', Kementrian Kesehatan Republik Indonesia, pp. 1-100. Available at: http://www.depkes.go.id/resources/download/info-terkini/hasil-riskesdas-2018.pdf.

Kristina, H., Sartono, N. and Rusdi, R. (2015) 'Kadar Peroksida Lipid Dan Aktivitas Superoksida Dismutase Serum Darah Pada Penderita Diabetes Melitus Tipe 2', Bioma, 11(1), p. 1. doi: 10.21009/bioma11(1).1.

Latifa, A. (2015) 'Digital Repository Universitas Jember', p. 27. Available at: http://repository.unej.ac.id/bitstream/handle/123456789/65672/AinulLatifah101810401034.pdf?sequence $=1$.

Meidayanti Putri, N., Gunawan, I. and Suarsa, I. (2015) 'Aktivitas Antioksidan Antosianin Dalam Ekstrak Etanol Kulit Buah Naga Super Merah (Hylocereus Costaricensis) Dan Analisis Kadar Totalnya', Jurnal Kimia, 9(2), pp. 243-251.

Moazen, S. et al. (2013) 'Effects of freeze-dried strawberry supplementation on metabolic biomarkers of atherosclerosis in subjects with type 2 diabetes: A randomized double-blind controlled trial', Annals of Nutrition and Metabolism, 63(3), pp. 256-264. doi: $10.1159 / 000356053$.

Muttakin, Zulfajri, M. and Mariati (2019) 'Antioxidant Activity from SyzygiumCumini (L.) Skeels', Journal of Physics: Conference Series, 1232(1). doi: 10.1088/17426596/1232/1/012009.

Negara, J. K. et al. (2016) 'Aspek mikrobiologis, serta Sensori (Rasa, Warna,Tekstur, Aroma) Pada Dua Bentuk Penyajian Keju yang Berbeda', Jurnal Ilmu Produksi dan Teknologi Hasil Peternakan, 4(2), pp. 286-290. doi: 10.29244/jipthp.4.2.286-290.

Pratiwi, R. 2015. Pengaruh Penambahan Buah Duwet (Syzygium cumini) Terhadap Aktivitas 
Antioksidan dan Mutu Es Krim Skripsi. Universitas Kristen Satya Wacana Salatiga.

Sandhiutami, N. M. D. and Indrayani, A. A. W. (2011) 'Antioxidant Activity Test and Determination of Phenolic and Flavonoid Contents from Buah Merah (Pandanus conoideus LAM)', Jurnal Ilmu Kefarmasian Indonesia, 10. doi: 10.4018/978-1-60566-786-7.ch003.

Sanggur, Y. F. (2017) 'Kualitas Organoleptik dan Daya Leleh Es Krim Dengan Penambahan Presentase Buah Nenas (Ananas sativus) Berbeda', Skripsi, Fakultas Peternakan, Universitas Hasanuddin, Makasar.

Setiawan, B. and Suhartono, E. (2005) 'Tinjauan Pustaka Stres Oksidatif dan Peran Antioksidan pada Diabetes Melitus Oxidative Stress and The Roles of Antioxidant in Diabetes Mellitus', 55.

Ulfah Rahmayani, Delianis Pringgenies, A. D. (2013) 'Uji Aktivitas Antioksidan Ekstrak Kasar Keong Bakau (Telescopium telescopium) dengan Pelarut yang Berbeda terhadap Metode DPPH (Diphenyl Picril Hidrazil)', Diponegoro Journal of Marine Research, 2(4), pp. 36-45. doi: 10.14710/jmr.v2i4.3682.

Wati, ayu fatma (2018) 'Aplikasi perbandingan sari buah duwet (', 5(2), pp. 104-111.

Widiantara, T. (2019) 'Pengaruh substitusi ubi jalar ungu (Ipomoea batatas) serta perbandingan kacang koro (Canavalia ensiformis) dengan susu skim terhadap karakteristik es krim', Pasundan Food Technology Journal, 6(1), p. 51. doi: 10.23969/pftj.v6i1.1506. 